\title{
A Study on Frodo's Quest within the Framework of Joseph Campbell's Monomyth
}

\author{
Joseph Campbell'ın Monomiti Çerçevesinde Frodo'nun Arayışı Üzerine Bir \\ Inceleme
}

Mehmet Galip ZORBA *

\begin{abstract}
There is a privileged and multifaceted relationship between literature and myth, and this relationship is beyond analyzing literary works in terms of mythical elements they incorporate because what is mythic and what is literary are not so dissimilar. Holding this view, monomyth theory argues that there is actually a single story retold or rewritten in different ways over and over again throughout human history, and in this single story the hero always goes through same stages. Simply put, in any story the hero receives the call to adventure, steps into an unknown realm and returns after accomplishing his task. The Lord of the Rings is the product of J. R. R. Tolkien's efforts to create a mythology for England. Therefore, he skillfully merges characteristics of epics, legends, quest stories and myths into a single pot while creating Middle-earth and the characters. From this standpoint, The Lord of the Rings requires a mythic reading and analysis. To this end, this study aims to analyze the trilogy in terms of monomyth theory focusing on Frodo's quest. While doing so, how the monomythic pattern appears in The Lord of the Rings is taken into consideration rather than validating monomyth theory. Consequently, this study reveals that the pattern of Frodo's quest follows all the stages of monomyth in the same order delineated by Joseph Campbell.
\end{abstract}

Keywords: Fantasy fiction, J. R. R. Tolkien, The Lord of the Rings, Monomyth, Quest

Öz: Edebiyat ve mit arasında ayrıcalıklı ve çok boyutlu bir ilişki vardır ve bu ilişki edebi eserleri içerdikleri mitsel unsurlar açısından incelemenin ötesindedir, çünkü mitsel olan ve edebi olan aslında birbirlerinden çok da farklı değildir. Bu görüş çerçevesinde monomit kuramı insanlık tarihi boyunca sözlü ve yazılı olarak değişik yollarla tekrar tekrar yinelenen tek bir hikâye olduğunu ve bu tek hikâyede kahramanın her zaman aynı aşamalardan geçtiğini ileri sürer. Basitçe açıklamak gerekirse, kahraman maceraya bir çağrı alır, bilinmeyen bir dünyaya adım atar ve o dünyanın içerisinde görevini tamamladıktan sonra geri döner. Yüzüklerin Efendisi üçlemesi J. R. R. Tolkien'in İngiltere için bir mitoloji yaratma çabalarının bir sonucudur. Dolayısıyla hem Orta Dünya'yı hem karakterlerini yaratırken destanların, efsanelerin, arayış hikâyelerinin ve mitlerin özelliklerini oldukça becerikli bir şekilde tek bir potada birleştirmiştir. Bu açıdan, Yüzüklerin Efendisi üçlemesi mitsel bir okuma ve analiz gerektirmektedir. Bu çalışmanın amacı üçlemeyi Frodo'nun arayışına odaklanarak monomit açısından incelemektir. Bu inceleme sırasında monomit teorisinin geçerliliğinden ziyade monomitsel desenin Yüzüklerin Efendisi'nde nasıl bulunduğu dikkate alınmış ve çalışmanın sonucu olarak Frodo'nun arayışında desenin monomitin bütün aşamalarını Joseph Campbell'ın çizdiği aynı sırayla izlediği tespit edilmiştir.

Anahtar Sözcükler: Fantastik Kurmaca, J. R. R. Tolkien, Yüzüklerin Efendisi, Monomit, Arayış

\footnotetext{
* PhD, Akdeniz University, Faculty of Letters, Department of English Language \& Literature, Antalya. galipzorba@akdeniz.edu.tr, https://orcid.org/0000-0002-0100-2329
} 


\section{Introduction}

Since its publication, The Lord of the Rings has been the subject of much research analyzing the trilogy from different perspectives and theoretical frameworks. Combining various characteristics of traditional literature with his extraordinary inspiration and mastery in literature and linguistics, Tolkien created a literary trilogy considered the cornerstone of fantasy fiction (Pearce 1998; Foster 2001). Despite the praises given by the contemporary literary scholars and readers, the trilogy was harshly criticized shortly after its publication in 1954/1955 for being unrealistic and shapeless fiction, lacking elegance in literary style and the destruction of the conventions on which the world of modern fiction was based (Day1 2007). The reason behind these critiques was mainly the way Tolkien benefited from different tools to create his unique style, which was completely opposed to the conventions of fictions at that time (Carter 1969; Burns 2005). He skillfully merged characteristics of epics, legends, quest stories and myths into a single pot along with creating new races, entities and languages so as to make the fictional world he constructed more believable, coherent and consistent (Noel 1977). However, his actual aspiration was to create a mythology for England (Chance 2001). He explains his thoughts in a letter that he wrote to Milton Waldman:

... [England] had no stories of its own, not of the quality that I sought, and found (as an ingredient) in legends of other lands. There was Greek, and Celtic, and Romance, Germanic, Scandinavian, and Finnish (which greatly affected me); but nothing English... Of course there was and is all the Arthurian world, but powerful as it is, it is imperfectly naturalized, associated with the soil of Britain but not with English; and does not replace what I felt to be missing (Carpenter \& Tolkien 2012, 160).

As can be understood from the quotation given above, Tolkien was inspired from various mythologies and the influences of these mythologies from Norse mythology to Greek and Celtic mythologies are inherent not just in The Lord of the Rings but in his other literary works as well, which makes the trilogy valuable enough to be studied in mythical terms (Noel 1977; Chance 2001; Burns 2005; Zorba 2013).

\section{Myth as Literature and Joseph Campbell's Concept of the Monomyth}

Theories about myths have been discussed by several prominent scholars whose main concern is to put forward scientific explanations about the origins and functions of myths. Although myths are among the concerns of various disciplines from sociology, anthropology to psychology, and these disciplines also incorporate multiple theories of myths, it can be seen that these theories actually cluster around three main questions. Segal (2004) summarizes that the first question deals with the origin of myths and seeks answers as to how and why myths arise, the second question addresses the function of myths and tries to find out why and how myths persist, whereas the last question deals with myths as a subject matter focusing on whether the story that a myth tells involves literal explanation or symbolic description.

There is a privileged and multifaceted relationship between literature and myth and this relationship is beyond analyzing literary works in terms of mythical elements they incorporate as frequently seen in literature courses, because what is mythic and what is literary are not so dissimilar. Mythology is an important aspect of literature and that literature is a means of extending mythology (Coupe 2009). In this sense, myth as literature bifurcates into two main trajectories; first searching out mythic origins of literary works and second analyzing what recurs in myths and how they are rephrased (Segal 2004). Obviously, what is essential for such 
analysis is mythic reading which requires delving into the depths of meaning so as to transcend the literal meaning (Burrows et al. 1973; Segal 2009). Studies on mythic patterns are considered a part of the second trajectory, and they either focus on delineation of such patterns or the application of a given pattern to a literary text.

Campbell's monomyth is one of the most influential mythic patterns whose main concern is the myth of the hero. Obviously, he grounds his 1949 theory on the view that the way humans perceive, understand, question, explain and think are similar, and they have similar urges, wishes and motives, and thus human beings have been questioning and also trying to make sense of the world, and consequently, almost identical or slightly different stories emerge (Short, Lynch-Brown \& Tomlinson 2014). Campbell $(2004,1)$ explains his monomyth theory in his work The Hero with a Thousand Faces and claims that

Whether we listen with aloof amusement to the dreamlike mumbo jumbo of some red-eyed witch doctor of the Congo, or read with cultivated rapture thin translations from the sonnets of the mystic Lao-tse... it will be always the one, shape-shifting yet marvelously constant story that we find, together with a challengingly persistent suggestion of more remaining to be experienced than will ever be known or told.

As it is clear in the given quotation, although there are a considerable number of stories told or written all around the world, there is actually a single story or monomyth as Campbell (2004) names, which has been retold or rewritten in different ways over and over again throughout human history. The monomyth is actually the hero's journey and is about the courage hidden in the hero, the image of his spiritual and mental rebirth, and his eternal cycle of change (Campbell \& Cousineau 2003). As his monomyth is heavily centered on the hero, his theory is also called "the hero's journey" or "hero-myth" in which, as Campbell (2004) summarizes, the hero "ventures forth from the world of common day into a region of supernatural wonder" (28), and he "comes back from this mysterious adventure with the power to bestow boons on his fellow man" (28) after encountering "fabulous forces" (28), and doing marvelous deeds. This summary is also the outline of "the nuclear unit of the monomyth" (Campbell 2004, 28) consisting of three main stages: 'venturing into a supernatural realm' refers to the stage of departure, 'encountering with fabulous forces' refers to the stage of initiation, and 'coming back from this mysterious adventure' refers to the stage of return. These stages also involve sub-stages in different numbers. Campbell $(2004,228)$ also elaborates the pattern and elucidates its flexible nature as follows;

The changes rung on the simple scale of the monomyth defy description. Many tales isolate and greatly enlarge upon one or two of the typical elements of the full cycle... others string a number of independent cycles into a single series... Differing characters or episodes can become fused or a single element can reduplicate itself and reappear under many changes.

Likewise, researchers such as Kesti (2007) and (Cura 2018) also underline that some stories do not have all these sub-stages whereas some follow them in a different order, which is also evident in the findings of some other research in which the monomyth was used to analyze certain literary works or media products (see also Çopur 2012; Göze 2013; Alıç \& Alıç 2014). On the other hand, as Phillips (1975) states, the monomythic pattern may develop strictly following the order, yet not all stories live up to this pattern, and thus it may also develop in a more complicated or subtle way. The aim of this study is to analyze the trilogy in terms of monomyth theory focusing on Frodo's quest. While doing so, how the monomythic pattern 
appears in the trilogy is taken into consideration rather than validating the monomyth theory.

\section{Frodo's Departure}

\section{The Call to Adventure}

This is the very first stage of the monomyth and it "signifies that destiny has summoned the hero and transferred his spiritual center of gravity from within the pale of his society to a zone unknown" (Campbell 2004, 53). This call to adventure and journey to an unknown world is often made by a herald described as "dark, loathly, or terrifying, judged evil by the world" (Campbell 2004, 47). It is certain that the herald who makes the call is Gandalf because he exactly fits the description made by Campbell. He is well of aware that he is seen as "unpopular, a nuisance and a disturber of the peace" (Tolkien 2005, 41) by most of the hobbits in Hobbiton. Furthermore, some Hobbits "are actually accusing [him] of spiriting Bilbo away" and of plotting against Bilbo "to get hold of his wealth" (Tolkien 2005, 41).

In Frodo's case, the call to adventure is not presented clearly but subtly. Actually, the call to adventure is the result of a long process which starts with Bilbo's unexpected disappearance in the middle of the crowd during the birthday party. As Bilbo's legal heir, Frodo inherits everything Bilbo has including the One Ring. Although Frodo is not aware of the power of the Ring, Gandalf becomes suspicious and leaves the Shire to investigate the Ring. When he comes back after seventeen years, he does one last test throwing the Ring into the fire. After seeing the markings written in black speech with Elvish letters, Gandalf's suspicion leaves its place to certainty. Then, Gandalf gives a detailed account of the Ring and how to destroy it, which terrifies Frodo because in that speech it is implied that the Ring is his responsibility and destiny.

Behind that there was something else at work, beyond any design of the Ring-maker. I can put it no plainer than by saying that Bilbo was meant to find the Ring, and not by its maker. In which case you were also meant to have it. And that may be an encouraging thought (Tolkien 2005, 56).

Furthermore, it can be inferred from Gandalf's detailed account that Frodo and the Shire are at stake as well. Gandalf says: "[Sauron] knows that it is the One. And he has at last heard of hobbits and the Shire" (Tolkien 2005, 59) which means "he may be seeking for it now, if he has not already found out where it lies" (Tolkien 2005, 59). This scene is the moment that ends the call to adventure process. The call to adventure actually dictates that Frodo has to leave the Shire as it is not a secure place anymore. Accepting such a bitter truth is not always easy even for the most famous and bravest heroes such as Odysseus and Achilles, so Frodo refuses the call without fully grasping that destiny has summoned him.

\section{Refusal of the call}

Campbell (2004) explains that "the refusal of the call is essentially a refusal to give up what one takes to be one's own interest" (54) because the hero is "walled in boredom, hard work, or culture" (55). The hero is so blindly bound up in his secure lifestyle, daily routines and/or cultural perspectives that he is "a victim to be saved" (Campbell 2004, 55); his ordinary life is actually his prison and his daily routines and perspectives are his chains. Consequently, he is apathetic about the outside world and its problems no matter how vital they are as he is simply not able to fully grasp the significance of the call. In a similar vein, holding a fatalist perspective Kesti (2007) states that the hero cannot fully understand that the adventure or the quest is his destiny, as he does not want to be a part of the unfamiliar as he thinks he belongs to the familiar. After receiving the call, Frodo refuses the Ring saying: 
I do really wish to destroy it... or, well, to have it destroyed. I am not made for perilous quests. I wish I had never seen the Ring! Why did it come to me? Why was I chosen? (Tolkien 2005, 61).

It is clear that Frodo does not grasp that he is in grave danger and it is his destiny to be the ringbearer. Hence, he still wants to deny the responsibility and says: "I have so little of any of these things! You are wise and powerful. Will you not take the Ring?” (Tolkien 2005, 61). Acceptance of the call comes the moment when he realizes that he is the danger to the Shire and he says:

I hope that you may find some other better keeper soon. But in the meanwhile it seems that I am a danger, a danger to all that live near me. I cannot keep the Ring and stay here. I ought to leave Bag End, leave the Shire, leave everything and go away (Tolkien 2005, 62).

Although he accepts the call, Frodo's deep reluctance to depart dominates the first part of Chapter 3, which is mostly portrayed through his actions rather than words. Tolkien (2005) describes Frodo's reluctance as follows;

To tell the truth, [Frodo] was very reluctant to start, now that it had come to the point. Bag End seemed a more desirable residence than it had for years, and he wanted to savour as much as he could of his last summer in the Shire (67).

Frodo's refusal of the call is related to his regrets and denials, yet his reluctance after accepting the call can be explained by his uncertainty and anxiety. It should be noted that Frodo does not know where to head for, what ordeals he has to bear and what danger he will encounter, and more importantly he has no idea about how to cope with all of these, which paves the way for his anxiety until he hears unpleasantly strange-looking people inquire into his whereabouts. At that moment Frodo understands that it is time to depart, he immediately goes home and says: “Sam! Sam! Time!” (Tolkien 2005, 70).

\section{Supernatural Aid}

The supernatural aid is often provided by the protective figure "who is often a little old crone, old man, good-natured goddess" (Campbell 2004, 63) or "some little fellow of the wood, some wizard, hermit, shepherd, or smith" (Campbell 2004, 66). The protective figure may supply the hero with amulets, artifacts that will help him in his journey, or give him some valuable advice. In some studies such as Kirer's (2010), Gandalf is considered the protective figure and all the discussion of this stage is grounded on him. Although he seems the foremost example for this role, it should be noted that Gandalf is not among the company departing the Shire and Frodo meets with Gandalf only after he reaches Rivendell. Furthermore, Gandalf does not supply Frodo with amulets or artifact, the only thing that he gives Frodo is his not-to-use-the Ring advice which Frodo cannot follow. On the other hand, Kesti (2007) states that supernatural aid comes after Frodo crosses over the first threshold, and the provider of the aid is Tom Bombadil.

However, the scene corresponding to supernatural aid is clear. It is Gildor, the leader of a group of Elves with whom Frodo and his companions meet by chance while running away from the Black Riders. Gildor provides the hobbits with shelter and security. Ostensibly, there is nothing 'supernatural' on this occasion, yet the Elves themselves are supernatural. They live much longer than any other races in Middle-Earth and always look young. Besides, they have a good command of knowledge about almost everything in Middle-Earth. In addition, they are far-sighted and have a keen sixth sense, thus they can sometimes foresee or predict events before they happen. In this case, for example, the Elves know a lot about Frodo and he 
wonderingly asks Gildor "how do you know my name?", and Gildor replies “We know many things" (Tolkien 2005, 80). In addition to shelter and security, Gildor also gives advice to Frodo. At this point, it should be underlined that "Elves seldom give unguarded advice, for advice is a dangerous gift, even from the wise to the wise" simply because "[t]he Elves have their own labors and their own sorrows, and they are little concerned with the ways of hobbits, or of any other creatures upon earth" (Tolkien 2005, 84). Gildor also advises:

...if you demand advice, I will for friendship's sake give it. I think you should now go at once, without delay; and if Gandalf does not come before you set out, then I also advise this: do not go alone. Take such friends as are trusty and willing (Tolkien 2005, 87).

When it comes to Frodo's insatiable curiosity about the Black Riders, Gildor also advises "Flee them! Speak no words to them! They are deadly" (Tolkien 2005, 84).

\section{Crossing of the First Threshold}

Campbell (2004) associates the first threshold with the limits of the known world of the hero. Apparently, these limits refer to physical boundaries surrounding the known world, and what is waiting for the hero "beyond them is darkness, the unknown and danger" (71). However, the threshold per se is not enough to keep the hero within those boundaries because once accepting the call, the hero also determines to leave his known world. Accordingly, the threshold also needs a custodian which Campbell (2004) names the 'threshold guardian'. In The Lord of the Rings the scene corresponding to this stage is the moment when Frodo steps into the Old Forest. First of all, Tolkien locates the Old Forest between Buckland and Bree, so the forest functions as a natural boundary between these two lands. What's more, there is another boundary between Buckland and the Old Forest. It is called the Hedge (also known as the High Hay), a barrier hedge that the Hobbits of Buckland built a long time ago to protect their land from the attack of the aggressive trees of the Old Forest. Secondly, the Old Forest is actually the place where the unknown for Frodo begins. Merry Brandybuck's detailed account clearly portrays the tempestuous and perilous nature of the Old Forest.

But the Forest is queer. Everything in it is very much more alive, more aware of what is going on, so to speak, than things are in the Shire. And the trees do not like strangers. They watch you ... Occasionally the most unfriendly ones may drop a branch, or stick a root out, or grasp at you with a long trailer. But at night things can be most alarming... I thought all the trees were whispering to each other, passing news and plots along in an unintelligible language; and the branches swayed and groped without any wind. They do say the trees do actually move, and can surround strangers and hem them in (Tolkien 2005, 110).

In order to cross the threshold, Frodo passes through a tunnel beneath the Hedge whose end is "closed by a gate of thick set iron bars" (Tolkien 2005, 110) which obviously functions as the threshold guardian to keep all comers out. After Merry unlocks the gate and all of them pass through the gate, Merry says "There! You have left the Shire, and are now outside, and on the edge of the Old Forest." (Tolkien 2005, 110), which means they have just stepped into an unknown realm.

\section{The Belly of the Whale}

This stage is based on the view that "no creature can attain to a higher grade of nature without ceasing to exist" (Coomaraswamy 1941, 8). Having left his own world and stepped into the 
unknown, the hero has to leave self behind to find the necessary competence to accomplish the task. Accordingly, the hero has to die for his rebirth which "is symbolized in the worldwide womb image of the belly of the whale" (Campbell 2004, 83). Undoubtedly, it is not actual death but a pseudo-death which 'symbolizes the hero's final separation from self' and is often portrayed as the hero's spiritual metamorphosis.

Frodo's pseudo-death begins when Frodo and his companions are trapped by the BarrowWight shortly after they leave Tom Bombadil's house. While moving forward in the wilderness of Barrow-downs, the fog comes down and darkness falls. He gets lost while calling and looking for his friends in the dark. Fear takes him when Frodo realizes that he is alone. He is also chilled and fatigued so he stops near a barrow where he encounters with "a tall dark figure like a shadow against the stars" (Tolkien 2005, 140) saying "I'm waiting for you" (Tolkien 2005, 140). The Barrow-Wight leans over Frodo and seizes him with a firm and cold grip and Frodo faints. In this scene, Tolkien's choice of words connotes 'death'. Words such as 'darkness', 'alone', 'fear' and 'faint' bring 'death' into our minds whereas the word 'barrow' indicates grave or graveyard. Furthermore, Tolkien's choice of words such as 'tall', 'dark' and 'shadow' while describing the Barrow-Wight portrays this creature as 'the agent of death'.

Frodo's rebirth begins at the moment when he comes to himself. He can "recall nothing except a sense of dread" (Tolkien 2005, 140) but "there is a seed of courage hidden in the heart of the fattest and most timid hobbit, wailing for some final and desperate danger to make it grow" (Tolkien 2005, 140), yet Frodo is "neither very fat nor very timid" (Tolkien 2005, 140). Eventually, Frodo finds the courage in himself and decides to fight back. This scene is described as follows;

...the courage that had been awakened in him was now too strong: he could not leave his friends so easily... Suddenly resolve hardened in him, and he seized a short sword that lay beside him... With what strength he had he hewed at the crawling arm near the wrist, and the hand broke off... (Tolkien 2005, 141).

In addition, the pseudo-death-rebirth process recurs two more times in The Lord of the Rings. Kesti (2007) discusses that the scene in which Frodo is badly wounded by the Witch King of Angmar corresponds to pseudo-death and the scene in which he comes to himself in Rivendell represents his rebirth. However, it should be noted that the hero must have gains when he is reborn. In this case he does not gain anything leading him to a higher status of nature; on the contrary, his wound never completely recovers. The other pseudo-death occurs when Frodo is stung by Shelob, the giant female spider, and rebirth begins when he wakes up half-naked in Mordor having gained the uttermost courage, determination and motivation which he needs just before the final encounter with Dark Enemy (Petty 1979; Kesti 2007; Kirer 2010).

\section{Frodo's Initiation}

\section{The Road of Trials}

This stage involves challenging tests and ordeals for the hero and throughout this process the hero benefits from every advice, talisman and secret agent of his helpers, or there is "a benign power everywhere supporting him in his formidable task" (Campbell 2004, 89). There are different views as to where Frodo's road of trials begins; for some it starts when he leaves the Old Forest, whereas for others his departure from Rivendell best suits the beginning of this stage, yet what these different views have in common is that Frodo undergoes many tests and ordeals until he reaches Mount Doom, and this stage recurs over and over again throughout his journey. Campbell's (2004) description of this stage is helpful in determining the starting point 
of this stage in the trilogy. He states that the road of trials is the beginning of a long path which is full of dangers, victories, failures, "unretainable ecstasies, momentary glimpses of the wonderful land" and more importantly "moments of illumination" (100). Throughout this long path "dragons have now to be slain and surprising barriers passed-again, again, and again" (Campbell 2004, 100).

Accordingly, the view that Frodo's road of trials begins after the fellowship departs from Rivendell sounds more reasonable, simply because in the Council of Elrond, it is decided that the Ring must be destroyed and Frodo volunteers to be the ring-bearer and the Council agrees. The road of trails begins when Frodo and his company head for the Redhorn Gate. As Caradhras is one of the highest mountains in the area and the Redhorn Gate is notorious for its narrowness and steepness, this scene can be considered the initial point of the long and very dangerous path underlined by Campbell (2004). Frodo and his companions have to change course as the gate is watched by the servants of the Enemy and harsh winter conditions make everything worse. Instead of going over the mountain or around it, they decide to go under it, and head for the Mines of Moria which involves several scenes corresponding to passing surprising barriers and slaying dragons over and over again. The first barrier is the West-door of Moria. The company cannot find the door as "dwarf-doors are not made to be seen when shut, they are invisible and their own masters cannot find or open them, if their secret is forgotten" (Tolkien 2005, 304). After finding the door, they also have to solve the riddle to open it. The moment they solve the riddle and open the door, Frodo is attacked by a giant octopus and is saved by his companions. What's more, the company is also attacked by hundreds of orcs and trolls in the Chamber of Records. The company has to fight against several of them in order to survive, and Frodo is hit by a spear and is saved by the help of the mithril. Miraculously, the company passes another barrier and manages to get out of the chamber where they are trapped, and to top it all, the company jumps out of the frying pan into the fire. While fleeing from the orcs, the company encounters a Balrog named Durin's Bane. Balrogs are demon-like creatures, a mixture of darkness, shadow and fire, and are described as holding "a blade like a stabbing tongue of fire in its right hand and a whip of many thongs in its left hand" (Tolkien 2005, 329). Durin's Bane is the most formidable opponent that the company has met so far. Rather than fleeing Gandalf decides to fight back and defeats it. However, Durin's Bane seizes him with its whip and drags him also into the abyss.

\section{Meeting with the Goddess}

Campbell (2004) describes this stage as "the ultimate adventure". After passing the barriers and overcoming the dangers, the hero encounters a goddess-like figure which is often described as "the paragon of all paragons of beauty, the reply to all desire, the bliss-bestowing goal of every hero's earthly and unearthly quest" (101). This figure represents "the totality of what can be known" whereas the hero is "the one who comes to know". The goddess-like figure "lures, guides, bids the hero burst his fetters" (106). Campbell (2004) clearly emphasizes the superiority of the goddess-like figure in terms of her appearance and power. From this standpoint, the goddess-like figure in The Lord of the Rings is undoubtedly Lady Galadriel. Tolkien describes Lady Galadriel's physical appearance as follows;

Very tall [Galadriel and Celeborn] were, and the Lady no less tall than the Lord; and they were grave and beautiful. They were clad wholly in white; and the hair of the Lady was of deep gold... but no sign of age was upon them, unless it were in the depths of their eyes; for these were keen as lances in the starlight, and yet profound, the wells of deep memory (Tolkien 2005, 354). 
It is clear in the given quotation that Lady Galadriel's description almost perfectly matches with the description of the goddess-like figure given above. Her physical appearance is no less than those of Greek goddesses. Besides, she is ageless just like the goddesses seen in Greek myths. Burns (2005) also argues that there are significant similarities between Lady Galadriel and Morrigan, the goddess of fertility in Celt mythology. The soil that Lady Galadriel gives Sam as a gift can be given as an example. Sam uses this gift to bring a new fertility to the Shire at end of the trilogy. In addition, Lady Galadriel also shares similarities with the Greek goddess Artemis, who is regarded as the goddess of forest March (2002). From this standpoint, it clear that Lady Galadriel is the lady of Lothlórien but at the same time Tolkien also implies that she is the actual ruler of the forest and her power is ubiquitous in Lothlórien. Lady Galadriel's power comes from her wisdom and knowledge whose sources are her special water-mirror which "shows things that were, and things that are, things that yet may be" (Tolkien 2005, 362), and her invisible ring named Nenya (also known as the Ring of Water). It is one of the Rings of Power given to the Elves of Middle-earth, and in Unfinished Tales, Tolkien (1980) states that Lady Galadriel has been using its power for protection and concealment from evil along with beautifying Lothlórien. Furthermore, Lady Galadriel also lets Frodo use her mirror, yet she also warns Frodo saying:

You may learn something, and whether what you see be fair or evil, that may be profitable, and yet it may not. Seeing is both good and perilous. Yet I think, Frodo, that you have courage and wisdom enough for the venture, or I would not have brought you here. Do as you will! (Tolkien 2005, 363).

At this point, it is clear that Lady Galadriel represents "the totality of what can be known" and Frodo takes the role of "the one who comes to know". Besides, as the goddess-like figure, she lures and bids Frodo to break his chains by leaving the ultimate decision to Frodo.

\section{Woman as the Temptress}

In many myths such as Helen of Troy and Circe, woman is most often portrayed as 'the destroyer of the hero' tempting him to act against the social conventions or to give up pursuing his task (Burrows et al. 1973). In a similar vein, Campbell (2004) also associates temptation with 'woman', yet this association is metaphorical, and thus it does not necessarily have to be a woman or a female figure who tempts the hero. The actual point that Campbell (2004) tries to emphasize is that there is always someone or something that tries to tempt the hero away from his path (Kesti 2007). In Frodo's case, this temptation happens more than once. When the company is in Lothlórien, using her psychic powers Lady Galadriel tempts each member of the company so as to test their loyalty and dedication to the task.

Each had felt that he was offered a choice between a shadow full of fear that lay ahead, and something that he greatly desired: clear before his mind it lay, and to get it he had only to turn aside from the road and leave the Quest and the war against Sauron to others (Tolkien 2005, 358).

In addition to Lady Galadriel, the Ring also acts as another temptress since it is always trying to stray Frodo from his task which is to reach Mount Doom and destroy the Ring. However, the instructions given by Elrond are also clear:

On him alone is any charge laid: neither to cast away the Ring, nor to deliver it to any servant of the Enemy nor indeed to let any handle it, 
save members of the Company and the Council, and only then in gravest need (Tolkien 2005, 281).

In addition to these instructions, Gandalf many times warns Frodo not to use the Ring. However, the Ring always tempts Frodo to use it simply because when it is worn, it becomes easier for Sauron to find it. Accordingly, wearing the Ring threatens the success of the task. After the company departs from Rivendell, Frodo violates this rule twice; once in Amon Hen while fleeing from Boromir and once in Mount Doom just as he is about to destroy the Ring. Furthermore, the Ring also tempts other people to possess it. In Amon Hen, Boromir tries to take the Ring from Frodo first by offering help for his burden, then trying to persuade him to use the Ring for good purposes, and lastly trying to usurp it saying "If any mortals have claim to the Ring, it is the men of Númenor, and not Halflings. It is not yours save by unhappy chance. It might have been mine. It should be mine. Give it to me!” (Tolkien 2005, 399).

\section{Atonement with the Father}

This stage involves the hero's symbolic encounter with a god-like figure who represents the father archetype, and this encounter is often turbulent and troublesome for the hero. Campbell (2004) associates this encounter with a sense-making process which requires experience and maturity. At the beginning of his journey, the hero is not mature enough to understand "how sickening and insane tragedies of this vast and ruthless cosmos are completely validated in the majesty of Being" (Campbell 2004, 135), but then he reaches the point of maturity in which he is able "to open his soul beyond terror" and for a moment he catches "a glimpse of the source" (Campbell 2004, 135), and at that moment "he beholds the face of the father, understands-and the two are atoned" (Campbell 2004, 135). However, this encounter is not always similar to a father and son reunion: on the contrary, this is often portrayed as the final confrontation between the hero and the enemy which is expected from the very first moment when the hero accepts the call (Petty 1979). Besides, the god-like figure is often portrayed as tyrannical and merciless namely as an 'ogre' (Segal 2004), the hero is set against the god-like figure, so as to take his position (Kesti 2007).

In Frodo's case, the Dark Lord, Sauron, is the hero's father figure who is described as a demonic and full of evil opponent whose existence is spiritual rather than physical. As the ringbearer Frodo is assigned to destroy the Ring, which also means the destruction of the father figure simply because a part of Sauron and much of his power are embedded in the Ring. Whether Frodo is intent on taking Sauron's position or on destroying the Ring is highly debatable. Although Frodo says "I will do now what I must" (Tolkien 2005, 401), Harvey (2003) argues that his transformation from the ring-bearer into the would-be the Lord of the Rings is implied. He also states that after wearing the Ring in Amon Hen, Frodo's internal struggle is so powerful that he resists taking it off despite the threat of being found by the Eye of Sauron, which can be interpreted as his ongoing internal struggle between his ring-bearer identity and his would-be the Ring master desire. Frodo's intentions may be debatable, yet there is a fact that he decides not to destroy the Ring, which also means he decides not to destroy his father figure. Just as he is about to throw the Ring into the fire of Mount Doom, he says: "I have come. But I do not choose now to do what I came to do. I will not do this deed. The Ring is mine!" (Tolkien 2005, 945). Then, he cannot resist the uttermost tempting nature of the Ring. He wears the Ring and vanishes. Once the Ring is worn, the Eye of Sauron starts to gaze into the depths of Sammath Naur, a hall within Mount Doom where the Ring was forged and where it can only be destroyed. This is the moment of Frodo's atonement with Sauron because at that moment Frodo sees his father figure and thoroughly understands what the Ring means for him and for himself. Just like Isildur, the first ring-bearer, Frodo is not able to resist the feeling of 
claiming the Ring, and thus fails to destroy it when he is so close to the achievement. Accordingly, the two, the hero and the god-like father figure, are atoned because it is Gollum who accidentally falls into the fire of Mount Doom holding his precious in his hands and destroys it.

\section{Apotheosis}

After the goddess is met, the father is atoned and the threat is eliminated, the moment of apotheosis comes for the hero. Campbell (2004, 149-150) describes the state of apotheosis as the moment in which "images and ideas of good and evil have been surpassed" and the hero no longer desires and fears because "all the gods have been subsumed" in him. As Worstell (2017) clarifies, this is the point of self-awareness which the hero achieves to reach a better understanding of himself. Eventually, the one who comes to know has transformed into the knower, and thus is relieved from his fear and desire.

Enduring all the ordeals, resisting his internal desires and surviving all the dangers, Frodo succeeds in bringing the Ring into the depths of Sammath Naur. In this way, he somehow leads to the destruction of the Ring even if he does not destroy it himself. The fact that Frodo declares himself as the sole owner of the Ring clearly indicates that his fears turn into desires. However, he gains knowledge and perception from this experience. After the Ring is destroyed, he reaches the position of the hero, the one who succeeds at what the others only attempt. Then, he is eventually relieved from all his desires and fears. Tolkien $(2004,947)$ elaborately portrays Frodo's relief as follows;

'Well, this is the end, Sam Gamgee,'... And there was Frodo, pale and worn, and yet himself again; and in his eyes there was peace now, neither strain of will, nor madness, nor any fear. His burden was taken away. There was the dear master of the sweet days in the Shire.

The relief leads to a full realization of what happened. Frodo realizes how close the threat was and says "I could not have destroyed the Ring. The Quest would have been in vain, even at the bitter end" (Tolkien 2005, 947).

\section{The Ultimate Boon}

Campbell (2004) associates the boon with treasures or something precious for the gods such as ambrosia or fire, and the hero must steal the boon, yet in such a case "gods may be oversevere, overcautious" (168), and thus "when in this mood even the highest gods appear as malignant, life-hoarding ogres, and the hero who deceives, slays, or appeases them is honored as the savior of the world" (168). After the hero takes the boon, the whole world explodes but "the miracle of miracles" happens and though "all is destroyed, all is renewed, revivified, and made glorious with the effulgence of true being" (177).

The Fellowship plans a trick against Sauron so that Frodo and Sam can more easily reach Sammath Naur to destroy the Ring and save all the living beings in Middle-earth from the danger of bondage and slavery. Gandalf and Aragorn reach the Black Gate, the main entrance of Mordor, with an army so as to distract the attention of the Eye of Sauron from the Ring and they succeed. Sauron deploys all his forces right in front of the Black Gate and unintentionally evacuates the area between Frodo and Sammath Naur which is the only place where the Ring can be destroyed. When Frodo wears the Ring one last time, Sauron realizes the trick. This scene is described as follows;

The Dark Lord was suddenly aware of him, and his Eye piercing all shadows looked across the plain to the door that he had made; and the 
magnitude of his own folly was revealed to him in a blinding flash, and all the devices of his enemies were at last laid bare (Tolkien 2005, 946).

Every action that Sauron takes after being tricked reveals his wrath, fear and struggle to survive. All his clever plans, stratagems and his forces become useless. He makes a last ditch effort to survive and project his wrath, yet all his evil deeds are in vain as the Ring is destroyed. Tolkien $(2005,947)$ describes the explosion coming after the Ring as follows;

Towers fell and mountains slid; walls crumbled and melted, crashing down; vast spires of smoke and spouting steams went billowing up, up, until they toppled like an overwhelming wave, and its wild crest curled and came foaming down upon the land. And then at last over the miles between there came a rumble, rising to a deafening crash and roar; the earth shook, the plain heaved and cracked, and Orodruin reeled.

Apparently, the destruction of the Ring symbolizes that Sauron has eternally lost his power, and Frodo is seen as the main actor who saves Middle-earth. Accordingly, as Campbell (2004) underlines, the honor of 'the savior of Middle-earth' is bestowed upon Frodo. Due to his success, he is also honored with the assignment of the crown-bearer of Aragorn at his coronation. Furthermore, Arwen, the Elven Queen, says "All that was done by that power is now passing away" (Tolkien 2005, 974), which clearly indicates that Middle-earth starts to be renewed and revivified.

\section{Frodo's Return}

\section{Refusal of the Return}

Possessing the boon is not an end for the hero; it is the beginning of another stage. The boon is a "life-transmuting trophy" so the hero must return home "where the boon may redound to the renewing of his community or the whole world" (Campbell 2004, 179). Similar to the refusal of the call, this responsibility is also often refused by the hero as he is too selfish to use the boon for others' good, he does not want to leave the pleasures that this new world offers, or his failure shames him into refusing the return (Cura 2018).

“In Frodo's case, the boon is not a treasure or an elixir of life but the destruction of the Ring, which means Sauron's bitter end. After the Ring is destroyed, Frodo is seen as the hero of the quest who put an end to Sauron's evil desires. From this standpoint, the actual ultimate boon is no one but Frodo himself whose story and self-sacrifice are the things that have brought peace and unity to Middle-earth. As Indick (2012) enunciates, in some myths, the boon is also the symbol of the hero himself as the hero is also a link between mortals and the gods just like in the case of Jesus Christ whose spirit and message will redeem mankind. Frodo in many ways is a Christ-like character. Frodo's mortal nature finds accord with the life of Jesus and especially it is Frodo's self-sacrifice that makes him appear most like Jesus (Padley \& Padley 2010). When it comes to Frodo's refusal of the return, his pathetic mood just after his triumph indicates his refusal. Despite Sam's hopeful and never-give-up spirit, Frodo is ready to surrender himself to death. While they are discussing on which way to go among the ruins of Mordor, Frodo says "Hopes fail. An end comes. We have only a little time to wait now. We are lost in ruin and downfall, and there is no escape" (Tolkien 2005, 950). The reason behind Frodo's refusal is his sense of failure because he cannot resist the Ring's temptation and uses it at the most inappropriate moment. Frodo's refusal turns into acceptance of the return when he sees Gandalf on the back of a giant eagle named Gwaihir. 


\section{The Magic Flight}

The magic flight is the symbol the hero's escape from the place where he accomplishes his task. As Campbell (2004) describes, if the hero attains the trophy against the opposition of its guardian or he wishes to return to his own world, then his wishes and struggles for return are hampered by the god and demons. In Frodo's case, both situations are apparent in that he accomplishes his task despite all Sauron's servants, and Frodo's escape from Mordor is also hindered by the devastation of Mordor. In other words, there is no way out from Mordor except for a magic flight which is described in the trilogy as follows;

And even as he [Gwaihir] espied them and came swooping down, he saw them fall, worn out, or choked with fumes and heat, or stricken down by despair at last, hiding their eyes from death ... and down swept Gwaihir, and down came Landroval and Meneldor the swift; and in a dream, not knowing what fate had befallen them, the wanderers were lifted up and borne far away out of the darkness and the fire (Tolkien 2005, 951).

\section{Rescue from Without}

Accomplishment of the task does not necessarily mean that all threats and danger for the hero are eliminated as his quest only ends when he arrives home. Although his return begins with the magic flight, there is still a long way to home and during his return journey the hero also faces hardship and tests. In such a case, he is often in need of someone's assistance for his return, or as Campbell (2004) describes, the hero is "brought back from his supernatural adventure by assistance from without" (192). However, Frodo does not faces threats and tests on the way back to home. Besides, what brings Frodo back to the Shire is not someone but his yearning for his home. Frodo displays his homesickness through his actions and utterances. After Aragorn's coronation, he goes to the King and says "I wish to go back to the Shire. I beg leave to depart soon" (Tolkien 2005, 974). On the way back to home, Frodo's first destination is Rivendell, and after staying with Bilbo for some time, Frodo's homesickness urges him to depart once again. Although the main urge for his return is yearning for his home, Frodo is still in need of his friend's assistance as his wound frequently troubles him. Sam accompanies him as he has been doing so since they left the Shire. Furthermore, Pippin and Merry also join the company along with Gandalf.

\section{Crossing of the Return Threshold}

Crossing of the return threshold is a formidable task for the hero as the threshold does not symbolize a physical limitation that the hero needs to overcome. The actually obstacle to the return is the hero's internal boundaries between his ordinary world he yearns for and the new world he is used to. As Campbell (2004) underlines, the real problem is "to accept banalities and noisy obscenities of life as real after an experience of the soul-satisfying vision of fulfillment, the passing joys and sorrow" (202-203). Frodo is right in the middle of the battle between these two worlds. Although he is homesick and full of desires to return, he becomes hesitant about the Shire as he gets near his home. At the Ford of Bruinen, Frodo begins to question what return means and says "Though I may come to the Shire, it will not seem the same; for I shall not be the same. I am wounded with knife, sting, and tooth, and a long burden. Where shall I find rest?” (Tolkien 2005, 989). When the hobbits eventually return to the Shire, they immediately realize that there is something wrong with the Shire. The social order in the Shire is totally disturbed. There are foreigners ruining gardens, giving orders, establishing rules and punishing those who violate the rules. This is the moment when Frodo decides to save the Shire, and thus this is the moment Frodo crosses over the return threshold. 


\section{Master of the Two Worlds}

In this penultimate stage, the battle between the two world ends and the hero finds a balance between them (Campbell 2004). The hero's supernatural experiences and his success makes him the master of that world, yet getting used to his ordinary life and purging himself of all hesitations, dilemmas and questions makes him the master of the ordinary world. All the hobbits in the Shire under the leadership of Frodo and his companions fight against the ruffians, all together clean the Shire from all those people including Saruman, the leader of the ruffians. Just before being expelled from the Shire, addressing Frodo, Saruman says "You have grown, Halfling. Yes, you have grown very much. You are wise, and cruel. You have robbed my revenge of sweetness, and now I must go hence in bitterness, in debt to your mercy" (Tolkien 2005, 1019). This quotation clearly indicates Frodo's mastery in the two worlds. He gained wisdom and courage to deal with evil people during his quest and became victorious in the supernatural world. Now, he defeats the remains of the Dark Lord using what he gained from his quest and also becomes victorious in his own world. As the hero, Frodo is full of wisdom and mercy yet is also cruel when necessary.

\section{Freedom to Live}

Campbell (2004) associates freedom to live with dispelling the fear of death and seizing the day without concerns about the future and regrets about the past. From this standpoint, freedom to live bifurcates into social and individual dimensions in The Lord of the Rings. Social dimension of freedom to live shows itself with Frodo's return along with Sam, Merry and Pippin which brings hope, courage and the feeling of resistance to the Shire. Dispelling the fear of death, Hobbits of the Shire regain their freedom with the Battle of Bywater and the social order is restored. Tolkien $(2005,1016)$ describes the battle as follows;

At last all was over. Nearly seventy of the ruffians lay dead on the field, and a dozen were prisoners. Nineteen hobbits were killed, and some thirty were wounded... So ended the Battle of Bywater, 1419, the last battle fought in the Shire... In consequence, though it happily cost very few lives, it has a chapter to itself in the Red Book, and the names of all those who took part were made into a Roll, and learned by heart by Shire-historians.

As for the individual dimension of freedom to live, it related to no one but Frodo. After saving and reconstructing the Shire, everything seems to be normal again for a while until Frodo's wound starts to trouble him once again. Frodo knows his wound can never heal in Middle-earth, as the wound opened by a Morgul knife can never be totally cured. Therefore, Frodo makes a hard choice so as to live free from pain. He decides to join Gandalf and Bilbo and leave for Valinor in the hope of finding rest and peace he has long been looking for.

\section{Conclusion}

Monomyth theory has a significant role in demonstrating that mythology cannot be explained with a single theory (Leeming, 1998). Besides, what makes this pattern so influential is not the theory or theories it is based on but the universal nature of myths (Segal 2013). Accordingly, as Campbell (2004) states, there is actually a single story of the hero which is continuously retold regardless of culture, geography and religion, yet the delineation of this pattern in literary works requires a mythic reading so as to go beyond the literal meaning. When such a reading is done, it is possible to see that heroes of different cultures follow the same path, monomyth.

"From the standpoint of monomyth, this study aims to analyze Tolkien's The Lord of the Rings. 
While doing so, the focus of study is on the examination of the monomyth as it appears in the trilogy rather than validating Campbell's theory. Besides, Tolkien's works require such an analysis as they were written with the purpose of creating a mythology for England (Chance 2001). When it comes to the traces of monomythic stages in The Lord of the Rings, findings related to Frodo's quest reveal that the trilogy involves each stage of monomyth following the same order as stated by Campbell. However, it should be noted that literary studies require interpretation of texts which often contain idiosyncratic but subjective traits, and thus the innate subjectivity of literary studies often results in unique and original inferences, yet it also makes findings questionable compared to other fields in social sciences such as psychology or sociology (Klarer 2011). This aspect of literary studies is useful to explain broad and subtle descriptions in Campbell's monomythic stages along with disagreements among the studies which approach from Campbell's monomyth The Lord of the Rings. In this sense, this study also reveals that the monomythic pattern delineated in this study is not entirely the same as those stated in Petty's (1979), Kesti's (2007) and Kurer's (2010) studies. Moreover, there are also strong disagreements among these studies in terms of the appearance of monomyth. Yet, it should be underlined that these disagreements are not the result of misinterpretation but of subjective interpretation, which eventually results in idiosyncratic delineations of monomythic pattern in these studies. 


\section{REFERENCES}

Alıç F. \& Alıç S. (2014). "Campbell'in Monomit Kuramı Bağlamında Gezi’nin Kırmızılı Kadın'ı: Siyasi Bir Simgenin Sonsuz Yolculuğu”. Turkish Studies 9/5 (2014) 185-210.

Burns M. (2005). Perilous Realms: Celtic and Norse in Tolkien’s Middle-earth. Toronto 2005.

Burrows D. J., Lapides F. R. \& Shawcross J. T. (1973). Myths and Motifs in Literature. USA 1973.

Campbell J. \& Cousineau P. (2003). The Hero's Journey: Joseph Campbell on His Life and Work (The Collected Works of Joseph Campbell). Canada 2003.

Campbell J. (2004). The Hero with a Thousand Faces. New Jersey 2004.

Carpenter H. \& Tolkien C. (2012). The letters of J. R. R. Tolkien. USA 2012.

Carter L. (1969). A Look Behind the Lord of the Rings. New York 1969.

Chance J. (2001). Tolkien's Art: A Mythology for England. Kentucky 2001.

Coomaraswamy A. K. (1941). “Akimcanna: Self-Naughting”. New Indian Antiquary 3/1 (1941) 1-16.

Çopur G. (2012). "Ruh Adam Romanında Kahramanın Sonsuz Yolculuğu: Yasak Aşs’ın Döngüsü”. Turkish Studies 7/2 (2012) 837-844.

Coupe L. (2009). Myth. New York 2009.

Cura N. (2018). Campbell'in Monomyth Çerçevesinden Bilbo'nun Kahramanin Yolculuğu. Unpublished MA Thesis. Tekirdağ University, Tekirdağ 2018.

Dayı E. (2007). A Stylistic Analysis of J R. R. Tolkien's the Lord of the Rings. Unpublished M. A. Thesis. Selçuk University, Konya 2007.

Foster R. (2001). Tolkien's World from A to Z: The Complete Guide to Middle-earth. New York 2001.

Göze F. E. (2013). "Kahramanın Yolculuğu: Beyazperdede Çocukların Kahraman Olma Macerası". Turkish Studies 8/8 (2013) 1793-1804.

Harvey G. (2003). The Origins of Middle-Earth for dummies. New Jersey 2003.

Indick W. (2012). Ancient Symbology in Fantasy Literature: A Psychological Study. North Carolina 2012.

Kesti T. (2007). Heroes of Middle-Earth: J. Campbell's Monomyth in J. R. R. Tolkien's The Lord of the Ring. Unpublished Pro-Graduate Thesis. University of Jyväskylä, Finland 2007.

Kirer O. (2010). The Archetypal Criticism of J. R. R. Tolkien's the Lord of the Rings. Unpublished M. A. Thesis. Erciyes University, Kayseri 2010.

Klarer M. (2011). An Introduction to Literary Studies. Oxford 2011.

Leeming D. A. (1998). Mythology: The Voyage of the Hero. Oxford 2002.

March J. (2002). Cassell's Dictionary of Classical Mythology. London 2002.

Pearce J. (1998). Tolkien: Men and Myth. London 1998.

Petty A. C. (1979). One Ring to Bind Them All: Tolkien's Mythology. Alabama 1979.

Phillips S. R. (1975). “Monomyth and literary criticism”. College Literature 2/1 (1975) 1-16.

Segal R. (2013). "Freudian and Jungian Approaches to Myth: The Similarities”. Eds. L. Burnett, S. Bahun \& R. Main, Myth, Literature and the Unconscious (2013) 101-119. London.

Segal R. A. (1997). Joseph Campbell: An Introduction. New York 1997.

Segal R. A. (2004). Myth: A very short introduction. Oxford 2004.

Segal R. A. (2009). "Myth". Ed. R. A. Segal, The Blackwell Companion to the Study of Religion (2009) 337-357. Malden.

Short K. G., Lynch-Brown C. \& Tomlinson C. M. (2014). Essentials of Children's Literature. Massachusetts 2014.

Tolkien J. R. R. (1980). Unfinished Tales of Númenor and Middle-earth. London 1980.

Tolkien J. R. R. (2005). The Lord of the Rings. London 2005.

Worstell R. C. (2017). The Art of Wonk. Midwest 2017.

Zorba M. G. (2013). “The Influences of Different Mythologies in Tolkien's the Lord of the Rings". The $7^{\text {th }}$ IDEA Conference (17-19 April 2013), Denizli/Turkey. 